\title{
Peranan Dan Fungsi Praperadilan Dalam Penegakan Hukum Pidana Di Polda Jateng
}

\author{
Dodik Hartono $^{*}$, Maryanto $^{* *}$, Djauhari $^{* * *}$ \\ * Mahasiswa Program Magister (S2) Ilmu Hukum Fakultas Hukum UNISSULA Semarang, email \\ dodik_hartono59@yahoo.com \\ ** Dosen Fakultas Hukum UNISSULA Semarang \\ ${ }^{* * *}$ Dosen Fakultas Hukum UNISSULA Semarang
}

\begin{abstract}
ABSTRAK
Penelitian dengan judul Peranan Dan Fungsi Praperadilan Dalam Menegakkan Hukum Pidana di Polda Jateng. Berdasarkan uraian dalam Tesis ini, permasalahan yang akan yang akan di teliti adalah: 1) Bagaimanakah fungsi dan peran praperadilan dalam penegakan hukum di Indonesia berdasarkan peraturan perundang-undangan yang berlaku? 2) Apa hambatan dalam pelaksanaan fungsi dan peran pra peradilan dalam penegakan hukum di Polda Jateng? 3) Bagaimanakah solusi dari hambatan dalam pelaksanaan fungsi dan peran pra peradilan dalam penegakan hukum di Polda Jateng?

Hasil penelitian menyimpulkan bahwa : 1) Maksud dan tujuan utama yang hendak ditegakkan dan dilindungi, dalam proses praperadilan yaitu tegaknya hukum dan perlindungan hak asasi tersangka dalam tingkat pemeriksaan penyidikan dan penuntutan. Pasal 1 butir 10 KUHAP dipertegas dalam Pasal 77 KUHAP yang menyebutkan Pengadilan Negeri berwenang untuk memeriksa dan memutus, sesuai dengan ketentuan yang diatur dalam undang-undang. Wewenang pengadilan untuk mengadili dalam praperadilan dijelaskan dalam Pasal 95 KUHAP. 2) Hambatan dalam pelaksanaan fungsi dan peran praperadilan dalam penegakan hukum di Polda Jateng meliputi : a. hakim lebih banyak memperhatikan perihal dipenuhi atau tidaknya syarat-syarat formil penangkapan dan penahanan, atau ada tidaknya perintah penahanan dan sama sekali tidak menguji dan menilai syarat materilnya. b. setiap pelaksanaan upaya paksa selalu ada perenggutan HAM. c. pemeriksaan untuk melakukan penahanan, masih ada penyalahgunaan dalam tahap penyidikan oleh Polisi dan penuntutan oleh jaksa. d. selain luasnya kewenangan penyidikan dalam menentukan bukti permulaan yang cukup, pengawasan terhadap kewenangan tersebut juga lemah. 3) Solusi dari hambatan dalam pelaksanaan fungsi dan peran praperadilan dalam penegakan hukum di Polda Jateng meliputi : a. Diperlukan upaya kontrol terhadap setiap aparat penegak hukum pada lembaganya masing-masing secara vertikal. b. KUHAP perlu direvisi khususnya mengenai mekanisme saling mengawasi antara penegak hukum dan lembaga dalam subsistem peradilan. c. diperlukan peran aktif hakim dalam menggunakan kewenangannya pada saat pemeriksaan pokok perkara untuk mempertimbangkan penyidikan atau penuntutan yang tidak sesuai dengan ketentuan hukum acara atau yang melawan hukum guna menghindari penyalahgunaan HAM. d. dalam tahap ajudikasi, hakim seharusnya berkonsentrasi untuk menentukan hasil pembuktian di persidangan dan dalam tahap ini, hakim dapat menilai apa yang terjadi dalam tahap praajudikasi.

Kata Kunci : Peranan dan Fungsi, Praperadilan, Penegakan Hukum Pidana
\end{abstract}

\section{ABSTRACT}


Research with the title Role And Practice Function In Enforcing Criminal Law in Central Java Regional Police. Based on the description in this Thesis, the issues that will be examined are: 1) How is the function and role of pretrial in law enforcement in Indonesia based on the prevailing laws and regulations? 2) What are the obstacles in the implementation of pre-justice functions and roles in law enforcement in the Central Java Regional Police? 3) How is the solution of the obstacles in the implementation of functions and the role of pre-judiciary in law enforcement in Central Java Regional Police?

The results of the study conclude that: 1) The main purpose and objectives to be upheld and protected, in the pre-trial process, namely the enforcement of the law and the protection of human rights of suspects in the level of investigation and prosecution investigation. Article 1 point 10 of the Criminal Procedure Code is affirmed in Article 77 of KUHAP stating that the District Court has the authority to examine and decide upon, in accordance with the provisions stipulated in law. The jurisdiction of the courts to adjudicate in pre-trial is described in Article 95 of the Criminal Procedure Code. 2) Obstacles in the implementation of functions and the role of pretrial in law enforcement in Central Java Police include: a. judges pay more attention to whether or not the formal conditions for arrest and detention, or whether there is a detention order and not test and judge material requirements at all. b. every execution of forced efforts is always a rush of human rights. c. checks for detention, there is still abuse in the investigation stage by the Police and prosecution by the prosecutor. $d$. besides the extent of investigative authority in determining sufficient preliminary evidence, the oversight of the authority is also weak. 3) Solutions from obstacles in the implementation of functions and pretrial roles in law enforcement in Central Java Police include: a. Control of each law enforcement apparatus is required on each institution vertically. b. The Criminal Procedure Code needs to be revised, especially regarding the mechanism of mutual supervision between law enforcement and institutions within the judicial system. c. an active role of the judge in the use of authority at the time of examination of the principal matter to consider investigations or prosecutions that are not in accordance with the provisions of procedural law or against the law in order to avoid abuse of human rights. $d$. in the stage of adjudication, the judge should concentrate on determining the results of the evidence in the hearing and in this stage the judge can judge what happened in the pre-certification stage.

Keywords: Roles and Functions, Pretrial, Criminal Law Enforcement

\section{PENDAHULUAN}

Praperadilan merupakan lembaga yang lahir dari pemikiran untuk mengadakan tindakan pengawasan terhadap aparat penegak hukum (Polisi, Jaksa dan Hakim) agar dalam melaksanankan kewenangannya tidak menyalahgunakan wewenang, karena tidaklah cukup suatu pengawasan intern dalam instansi perangkat aparat hukum itu sendiri, namun juga dibutuhkan pengawasan silang antara sesama aparat penegak hukum.

Dihubungkan dengan kegiatan Penyidik yang implementasinya dapat berupa, misalnya penangkapan bahkan penahanan, maka hukum acara pidana melalui ketentuan-ketentuan yang sifatnya memaksa menyingkirkan asas yang diakui secara universal yaitu hak kebebasan seseorang. Hukum acara pidana memberikan hak kepada pejabat tertentu untuk menahan tersangka atau 
terdakwa dalam rangka melaksanakan hukum pidana materiil guna mencapai ketertiban dalam masyarakat. $^{1}$

Praperadilan secara tidak langsung melakukan pengawasan atas kegiatan yang dilakukan Penyidik polri dalam rangka penyidikan maupun Penyidik kejaksaan dalam tingkat penuntutan, mengingat tindakan penyidik pada dasarnya melekat pada instansi yang bersangkutan. Melalui lembaga Praperadilan ini maka dimungkinkan adanya pengawasan antara kepolisian dan kejaksaan dalam hal penghentian penyidikan dan penuntutan. Kewenangan dari lembaga praperadilan sendiri antara lain untuk memeriksa dan memutus : ${ }^{2}$

1. Sah tidaknya penetapan tersangka penangkapan, penahanan, penahanan, penghentian penyidikan, atau, penghentian penuntutan;

2. Ganti kerugian dan atau rehabilitasi bagi seseorang yang perkara pidananya dihentikan pada tingkat penyidikan atau penuntutan

Adanya asas praduga tak bersalah tersebut sesuai dengan prinsip yang terkandung dalam pembentukkan Undang-Undang Nomor 8 Tahun 1981 tentang Hukum Acara Pidana (selanjutnya disebut KUHAP), yang dijiwai prinsip perlindungan terhadap harkat dan martabat manusia. Hal tersebut pada prinsipnya juga sesuai dengan tujuan KUHAP yaitu untuk memberi perlindungan terhadap hak-hak asasi dalam keseimbangan dengan kepentingan umum.

Sebenarnya, putusan Hakim Sarpin ini bukan lah putusan pertama yang mengabulkan permohonan praperadilan atas sah tidaknya penetapan tersangka. Setidaknya, ada 1 (satu) putusan sebelum putusan Hakim Sarpin yang mengabulkan permohonan tersebut, yaitu putusan Hakim Suko Harsono dalam perkara praperadilan dnegan pemohon Bachtiar Abdul Fatah di Pengadilan Negeri Jakarta Selatan.

Pada tanggal 28 April 2015, Mahkamah Konstitusi dalam putusannya Nomor 21/PUU-XII/2014 memutuskan salah satunya bahwa Pasal 77 huruf a KUHAP adalah bertentangan dengan Undangundang Dasar Negara Republik Indonesia 1945 sepanjang tidak termasuk penetapan tersangka, penyitaan, dan penggeledahan. Artinya, dengan putusan MK ini, pengujian sah tidaknya penetapan harus termasuk dalam objek praperadilan.

Yang terakhir, beberapa waktu yang lalu, terdapat permohonan praperadilan atas sah tidaknya penetapan tersangka yang diajukan oleh Hadi Poernomo ke Pengadilan Negeri Jakarta Selatan. Hakim yang menyidangkan perkara tersebut, Haswandi, dalam amar putusannya, menyatakan bahwa sah tidaknya penetapan tersangka adalah objek yang dapat diperiksa pada tahap praperadilan.

Pada putusan MK yang menyatakan bahwa penetapan tersangka termasuk salah satu objek yang dapat diperiksa keabsahannya dalam praperadilan. Namun, perlu diingat, pernah ada putusan MK nomor 003/PUU-IV/2006 tertanggal 26 Juli 2006 yang pada intinya menyatakan bahwa penggunaan ajaran sifat melawan hukum materiil yang tercantum dalam penjelasan Pasal 2 Ayat (1) UU 31/1999 jo. UU 20/2001 tentang Pemberantasan Tindak Pidana Korupsi adalah bertentangan dengan UUD NRI 1945 dan tidak boleh dilakukan. Faktanya, dalam putusan kasasi perkara tindak

\footnotetext{
${ }^{1}$ Ratna Nurul Alfiah,1986. Praperadilan dan Ruang Lingkupnya, Akademika Pressindo, Jakarta, hlm 35.

2 Indonesia, Undang-undang tentang KUHAP, UU. No. 8 Tahun 1981, Lembaran Negara RI. No. 76 Tahun 1981,

Tambahan LN RI.No. 3209, pasal 77
} 
pidana korupsi nomor 2064 K/ Pid/ 2006 tanggal 8 Januari 2007 atas nama terdakwa H. Fahrani Suhaimi, Hakim Agung yang mengadili perkara tersebut tetap menggunakan ajaran sifat melawan hukum materiil. Fakta membuktikan bahwa ternyata hakim yang berada dalam naungan Mahkamah Agung belum tentu melaksanakan putusan MK. Hal ini menyebabkan pula adanya potensi hakimhakim yang berada dibawah naungan MA tidak melaksanakan putusan MK terkait penetapan tersangka yang masuk ke dalam salah satu objek praperadilan.

Dalam perkara praperadilan Budi Gunawan. Dalam perkara tersebut, Hakim Sarpin pada dasarnya tidak memeriksa mengenai bukti permulaan yang digunakan KPK dalam menetapkan Budi Gunawan sebagai tersangka, namun memeriksa apakah KPK berwenang melakukan proses hukum terhadap Budi Gunawan dan pada akhirnya Hakim Sarpin memutuskan bahwa KPK tidak berwenang memproses Budi Gunawan secara hukum karena Budi Gunawan tidak memenuhi kualifikasi pihakpihak yang dapat diproses hukum oleh KPK berdasarkan Pasal 11 UU 30/2002 tentang KPK, yaitu aparat penegak hukum atau penyelenggara Negara, mendapat perhatian yang meresahkan masyarakat, dan melibatkan. kerugian Negara paling sedikit Rp. 1.000.000.000,- (satu milyar rupiah), sehingga seluruh proses hukum yang dilakukan KPK dianggap tidak sah, termasuk penetapan tersangka yang dilakukan KPK terhadap Budi Gunawan. ${ }^{3}$

Kasus kedua adalah kasus yang menimpa Setya Novanto. Pada tanggal 17 Juli 2017 KPK mengumumkan penetapan Setya Novanto sebagai tersangka kasus korupsi pengadaan E-KTP. la diduga ikut mengatur agar anggaran proyek E-KTP senilai Rp.5,9 triliun disetujui anggota DPR. Selain itu, Novanto diduga telah mengondisikan pemenang lelang dalam proyek E-KTP. Bersama pengusaha Andi Agustinus alias Andi Narogong, Novanto diduga ikut menyebabkan kerugian negara Rp 2,3 triliun. Namun seiring berjalannya waktu, tepatnya tanggal 29 September 2017 status tersangka itu dibatalkan hakim praperadilan Pengadilan Negeri Jakarta Selatan Cepi Iskandar. ${ }^{4}$

Dari uraian di atas, maka penulis dalam pembuatan judul tesis ini mengambil judul "Peranan Dan Fungsi Praperadilan Dalam Penegakan Hukum Pidana Di Indonesia". Dari uraian tersebut diatas dapat dirumuskan suatu permasalahan sebagai berikut:

1. Bagaimanakah fungsi dan peran praperadilan dalam penegakan hukum di Indonesia berdasarkan peraturan perundang-undangan yang berlaku?

2. Apa hambatan dalam pelaksanaan fungsi dan peran pra peradilan dalam penegakan hukum di Polda Jateng?

3. Bagaimanakah solusi dari hambatan dalam pelaksanaan fungsi dan peran pra peradilan dalam penegakan hukum di Polda Jateng?

\section{Metode Penelitian}

Pendekatan yang digunakan adalah pendekatan yuridis sosiologis. Dalam penelitian ini, hukum dikonsepsikan sebagai suatu gejala empiris yang dapat diamati dalam kehidupan nyata. Jenis penelitian yang dipergunakan dalam menyelesaikan tesis ini adalah metode penelitian deskriptif yang

\footnotetext{
${ }^{3}$ http://www.hukumonline.com, diakses pada tanggal 22 November 2017, pukul 20.00.

4 http://nasional.kompas.com/read/2017/09/30/08450451/kronologi-novanto-tersangka-hingga-status-tersangkanyadibatalkan, , diakses pada tanggal 23 November 2017, pukul 16.00 .
} 
menggambarkan apa yang diperoleh dari lapangan peneltian, yaitu dilakukan dengan cara meneliti bahan pustaka (data sekunder) atau library research. ${ }^{5}$

Dalam penelitian yang menggunakan pendekatan yuridis sosiologis, pendekatan dengan metode ini bertujuan memperoleh pengetahun hukum secara empiris berdasarkan apa yang diperoleh di lapangan penelitian. Maka untuk memperoleh data yang mendukung kegiatan pengumpulan data dalam penelitian ini adalah dengan melakukan studi kepustakaan. Yakni dengan cara membaca, mencatat, mengkaji, serta mempelajari sumber-sumber tertulis. Data sekunder ini berguna sebagai landasan teori untuk mendasari penganalisaan pokok-pokok permasalahan yang ada dalam penelitian ini. Data sekunder dalam penelitian ini meliputi : a) Bahan hukum primer, yang terdiri dari: UndangUndang Dasar 1945; Kitab Undang-Undang Hukum Pidana; Undang-Undang Nomor 8 Tahun 1981 tentang Kitab Undang-Undang Hukum Acara Pidana; Undang-Undang Nomor 11 Tahun 2008 tentang Informasi dan Transaksi Elektronik; Undang-Undang Nomor 19 Tahun 2016 tentang Perubahan atas Undang-Undang Nomor 11 Tahun 2008 tentang Informasi dan Transaksi Elektronik; Keputusan Mahkamah Konstitusi Nomor 21/PUU-XII/2014; Keputusan Mahkamah Konstitusi Nomor 003/PUUIV/2006; b) Bahan hukum sekunder : Buku-buku, jurnal, dan dokumen hasil penelitian di bidang hukum khususnya masalah peran dan fungsi praperadilan dalam penegakan hukum di Indonesia; c) Bahan Hukum Tersier, yang terdiri dari : Kamus Bahasa Indonesia, Kamus Bahasa Inggris, Kamus Hukum, Ensiklopedia serta sarana ajar (hand out) tentang tata cara penulisan karya ilmiah.

Metode Pengumpulan Data meliputi : a) Kepustakaan, Penelitian ini menggunakan Library Research (studi kepustakaan) yaitu pengumpulan data yang diperoleh dari sumber-sumber literature, karya ilmiah, peraturan perundang-undangan serta sumber-sumber tertulis lainnya yang berhubungan dengan masalah yang diteliti sebagai landasan teori. Dari penelitian ini data yang diperoleh disebut data sekunder; Wawancara a) Cara Bebas Terpimpin, Dalam wawancara bebas terpimpin, pewawancara mengkombinasikan wawancara bebas dengan wawancara terpimpin, yang dalam pelaksanaannya pewawancara sudah membawa pedoman tentang apa-apa yang ditanyakan secara garis besar. Kelemahan wawancara: Tanya jawab menjadi kaku, formil, sehingga data kurang mendalam (seperti seorang hakim dengan seorang terdakwa). Kelebihan wawancara : a. Pertanyaan seragam, sehingga dapat melakukan kompirasi. b. Pembuktian hipotesis akan lebih mudah. c. Memungkinkan analisis data secara kualitatif. d. Simpulan lebih dapat diandalkan. b).Sampel Purposive Sampling Dalam penelitian ini penulis mengambil sampel dengan menggunakan teknik purposive sampling. Mengenai hal ini, bahwa purposive sampling dilakukan dengan cara mengambil subjek bukan didasarkan atas strata, random atau daerah tetapi didasarkan atas tujuan tertentu. ${ }^{6}$ Begitu pula menurut Sugiyono, purposive sampling adalah "teknik penentuan sampel dengan pertimbangan tertentu". Artinya setiap subjek yang diambil dari populasi dipilih dengan sengaja berdasarkan tujuan dan pertimbangan tertentu. ${ }^{7}$

\footnotetext{
5 Ediwarman, 2010. Monograf, Metodologi Penelitian Hukum, Medan: Program Pascasarjana Universitas Muhammadiyah Sumatera Utara, Medan, hlm. 24

${ }^{6}$ Arikunto Suharsimi. 2002. Prosedur Penelitian Suatu Pendekatan Praktek. Rineka Cipta, Jakarta. hlm. 183

${ }^{7}$ Sugiyono. 2010. Metode Penelitian Kuntitatif Kualitatif dan R\&D. Alfabeta : Bandung. hlm. 85
} 
Metode analisa data yang digunakan adalah deskriptif kualitatif, yaitu penguraian dari analisa data yang bertitik tolak pada informasi-informasi yang didapat dari responden untuk mencapai kejelasan masalah yang akan dibahas.

\section{HASIL PENELITIAN DAN PEMBAHASAN}

\section{Fungsi Dan Peran Praperadilan Dalam Penegakan Hukum Di Indonesia Berdasarkan Peraturan Perundang-Undangan Yang Berlaku Saat Ini}

Praperadilan merupakan bagian dari pengadilan negeri yang melakukan fungsi pengawasan terutama dalam hal upaya paksa terhadap tersangka oleh penyidik atau penuntut umum. Pengawasan yang dimaksud adalah pengawasan bagaimana seorang aparat penegak hukum melaksanakan wewenang yang ada padanya sesuai dengan ketentuan peraturan perundang-undangan yang ada, sehingga aparat penegak hukum tidak sewenang-wenang dalam melaksanakan tugasnya. Sedangkan bagi tersangka atau keluarganya sebagai akibat dari tindakan menyimpang yang dilakukan oleh aparat hukum dalam melaksanakan tugasnya berhak mendapat ganti kerugian dan rehabilitasi.

\section{Fungsi Praperadilan Pada Proses Pengawasan Penahanan dan Penangkapan Dalam Rancangan KUHAP.}

Maksud dan tujuan utama yang hendak ditegakkan dan dilindungi, dalam proses praperadilan yaitu tegaknya hukum dan perlindungan hak asasi tersangka dalam tingkat pemeriksaan penyidikan dan penuntutan. Oleh karena itu, dibuatlah suatu lembaga yang dinamakan praperadilan seperti yang diatur dalam Pasal 77 sampai dengan Pasal 83 KUHAP, guna kepentingan pengawasan terhadap perlindungan hal-hak tersangka dalam pemeriksaan pendahuluan. Kontrol tersebut dilakukan dengan cara-cara: ${ }^{8}$

(a) kontrol vertikal yaitu kontrol dari atas ke bawah; dan

(b) kontrol horisontal, yaitu kontrol ke samping, antara penyidik, penuntut umum timbal balik dan tersangka, keluarganya atau pihak lain.

Pasal 1 butir 10 KUHAP dipertegas dalam Pasal 77 KUHAP yang menyebutkan Pengadilan Negeri berwenang untuk memeriksa dan memutus, sesuai dengan ketentuan yang diatur dalam undang-undang menyatakan bahwa:

"Penghentian penuntutan bukanlah penyampingan perkara demi kepentingan umum yang menjadi wewenang Jaksa Agung".

Pasal 80 KUHAP menyebutkan:

"Permintaan untuk memeriksa sah atau tidaknya suatu penghentian penyidikan atau penuntutan dapat diajukan oleh penyidik atau penuntut umum atau pihak ketiga yang berkepentingan kepada Ketua Pengadilan Negeri dengan menyebutkan alasannya".

Pertimbangan tersebut adalah sarana pengawasan secara horisontal demi menegakkan hukum, keadilan, dan kebenaran. Mengingat, penuntut umum perlu menghindarkan diri dari

\footnotetext{
${ }^{8}$ Moch. Faisal Salam, Hukum Acara Pidana Dalam Teori dan Praktek, (Bandung : Mandar Maju, 2001), hlm. 322.
} 
praperadilan yang diselenggarakan berdasarkan Pasal 80 KUHAP. Saling kerjasama dalam menuntun pihak penyidik melakukan tugas kewenangannya dengan baik, lancar dan sempurna untuk kurun waktu sementara ini, adalah upaya agar pihak penuntut umum tidak terjerembab ke dalam pemeriksaan praperadilan.

\section{Norma Penahanan Dalam KUHAP}

Pengaturan penahanan dalam hukum Indonesia mengacu pada Pasal 20 KUHAP sampai dengan Pasal 31 KUHAP. Penahanan dalam KUHAP adalah penempatan tersangka atau terdakwa di tempat tertentu oleh penyidik atau penuntut umum atau hakim dengan penetapannya. ${ }^{9}$

Berdasarkan ketentuan di atas semua instansi penegak hukum mempunyai kewenangan untuk melakukan penahanan. Penahanan berdasarkan KUHAP dibedakan atas:

(1) Penahanan untuk kepentingan penyidikan. Dalam hal ini penyidik atau penyidik pembantu berwenang melakukan penahanan atas perintah dari penyidik. Mengenai ukuran dari kepentingan penyidikan ditentukan oleh kenyataan keperluan pemeriksaan penyidikan itu sendiri secara objektif. Penahanan tergantung kepada kebutuhan penyidik untuk menyelesaikan fungsi pemeriksaan penyidikan yang tuntas dan sempurna sehingga penyidikan benar-benar mencapai hasil pemeriksaan yang akan diteruskan kepada penuntut umum, sebagai dasar pemeriksaan di pengadilan. Jika pemeriksaan cukup, maka penahanan tidak diperlukan lagi kecuali ada alasan lain untuk tetap menahan tersangka. ${ }^{10}$

(2) Penahanan yang dilakukan oleh penuntut umum, yang bertujuan untuk kepentingan penuntutan. ${ }^{11}$

(3) Penahanan yang dilakukan oleh Peradilan. Penahanan ini bermaksud untuk kepentingan pemeriksaan di sidang pengadilan. Hakim berwenang melakukan penahanan dengan penetapan yang di dasarkan kepada perlu tidaknya penahanan dilakukan sesuai dengan kepentingan pemeriksaan di sidang pengadilan. ${ }^{12}$

\section{Dasar Penahanan}

Landasan penahanan meliputi dasar hukum, keadaan, serta syarat-syarat yang memberi kemungkinan bagi penegak hukum untuk melakukan penahanan. Semua unsur tersebut saling menopang sehingga jika salah unsur tersebut tidak ada, penahanan kurang memenuhi asas legalitas. Menurut Yahya Harahap, meskipun tidak dikualifikasi sebagai tindakan tidak sah (ilegal), kekurangan unsur tetap dianggap tidak memenuhi asas legalitas. Misalnya yang terpenuhi hanya landasan hukum (unsur objektif), tetapi tidak didukung unsur keperluan (unsur subjektif), atau tidak dikuatkan syaratsyarat yang ditentukan undang-undang, maka penahanan seperti ini kurang relevan dan tidak memenuhi urgensi. ${ }^{13}$

\footnotetext{
${ }^{9}$ Pasal 1 butir 21 KUHAP

${ }^{10}$ Pasal 20 ayat (1) KUHAP

${ }^{11}$ Pasal 20 ayat (2) KUHAP

${ }^{12}$ Pasal 20 ayat (2) KUHAP

${ }^{13}$ Sebagaimana dimaksud dalam Pasal 282 ayat (3), Pasal 296, Pasal 335 ayat (1), Pasal 351 ayat (1), Pasal 353 ayat (1), Pasal 372, Pasal 378, Pasal 379 a, Pasal 453, Pasal 454, Pasal 455, Pasal 459, Pasal 480 dan Pasal 506 KUHP, Pasal 25 dan Pasal 26 Rechtenordonantie (pelanggaran terhadap Ordonansi Bea dan Cukai, terakhir diubah dengan Staatsblad
} 


\section{a. Unsur yuridis}

Unsur pertama ini disebut sebagai dasar hukum, karena undang-undang sendiri telah menentukan pasal-pasal tindak pidana mana penahanan dapat diterapkan. Tidak semua tindak pidana dapat dilakukan penahanan atas tersangka atau terdakwa. Undang-undang telah menentukan secara umum dan terperinci pelaku kejahatan yang dapat dikenakan penahanan berdasarkan unsur yuridis. Pasal 21 ayat (4) KUHAP menegaskan, penahanan hanya dikenakan terhadap tersangka atau terdakwa yang melakukan atau mencoba melakukan tindak pidana, atau memberi bantuan dalam tindak pidana yang diancam dengan pidana penjara lima tahun atau lebih.

\section{b. Unsur Keadaan Kekhawatiran}

Semua keadaan yang mengkhawatirkan di sini adalah keadaan yang meliputi diri tersangka atau terdakwa. Pejabat yang menilai keadaan kekhawatiran bertitik tolak dari penilaian subjektif pejabat. Namun ada beberapa indikator yamg dapat digunakan untuk melihat unsur subjektif tersebut yakni: ${ }^{14}$

1). Potensi melarikan diri dapat dilihat dari tingkat mobilitas dari tersangka, profesi dan pekerjaan tersangka, dukungan keluarga untuk melarikan diri, serta jika tidak ditemukan domisili asli dari tersangka, atau tidak memiliki alamat tempat tinggal dan lain-lain.

2). Merusak atau menghilangkan barang bukti: bisa dilihat dari berapa persentase alat bukti yang didapatkan penyidik. Bisa juga dilihat jika alat bukti masih minim sedangkan ada potensi menghilangkan alat bukti. Atau melihat kondisi akses dan kemampuan maupun dukungan terhadap tersangka untuk menghilangkan alat bukti termasuk jika berpotensi mengancam saksi-saksi kunci.

Mengulangi tindak pidana dapat dilihat dari: catatan sejarah kriminal tersangka, kondisi dari korban, dan jenis perbuatanpidananya: misalnya perkosaan, pembunuhan, narkotika, dan teroris maka perlu prioritas penahanan.

\section{c. Unsur memenuhi syarat Pasal 21 ayat (1) KUHAP}

Disamping unsur-unsur penahanan di atas, penahanan harus memenuhi syarat sesuai Pasal 21 ayat (1) KUHAP, meliputi:

1. Tersangka atau terdakwa diduga keras sebagai pelaku tindak pidana yang bersangkutan;

2. Dugaan yang keras itu di dasarkan pada bukti yang cukup.

Perlu dikemukakan, syarat penahanan berbeda dengan syarat penangkapan, dimana bukti menjadi pembeda dari keduanya. Pada penangkapan, syarat bukti didasarkan pada bukti permulaan yang cukup. Sedangkan pada penahanan didasarkan pada bukti yang cukup. Dengan demikian syarat bukti dalam penahanan lebih tinggi kualitasnya daripada penangkapan.

KUHAP tidak menjelaskan mengenai bukti yang cukup. Namun jika melihat Pasal 62 ayat (1) dan Pasal 75 HIR ditemukan penjelasan bahwa penahanan harus didasarkan pada syarat: jika ada

Tahun 1931 No. 471), Pasal 1, Pasal 2 dan Pasal 4 UU Tindak Pidana Imigrasi (UU No. 8 Drt/1955), Pasal 36 ayat (7), Pasal 41, Pasal 42, Pasal 43, Pasal 47 dan Pasal 48 UU No. 9 Tahun 1976 tentang Narkotika.Undang-Undang Nomor 6 Tahun 2011 Tentang Keimigrasian dalam Pasal 109 menyatakan bahwaTerhadap tersangka atau terdakwa yang melakukan tindak pidana keimigrasian sebagaimana dimaksud dalam Pasal 118, Pasal 119, Pasal 120, Pasal 121, Pasal 122, Pasal 123, Pasal 126, Pasal 127, Pasal 128, Pasal 129, Pasal 131,Pasal 132, Pasal 133 huruf b, Pasal 134 huruf b, dan Pasal 135 dapat dikenai penahanan.

${ }^{14}$ Darwan Prinst, 1993. Praperadilan Dan Perkembangannya Di Dalam Praktek . Citra Aditya Bakti, Bandung.. hlm. 46 
keterangan-keterangan yang menunjukkan bahwa tersangka bersalah. Jadi dalam HIR syarat bukti untuk melakukan penahanan didasarkan pada patokan: bukti yang cukup untuk menyatakan bahwa tersangka atau terdakwa bersalah.

\section{Hambatan Dalam Pelaksanaan Fungsi Dan Peran Praperadilan Dalam Penegakan Hukum Di Polda Jateng}

Dalam praktik pemeriksaan praperadilan selama ini, ternyata hakim lebih banyak memperhatikan perihal dipenuhi atau tidaknya syarat-syarat formil penangkapan dan penahanan, atau ada tidaknya perintah penahanan dan sama sekali tidak menguji dan menilai syarat materilnya. Padahal syarat materil ialah yang paling menentukan seseorang dapat dikenakan upaya paksa. ${ }^{15}$

Menurut studi Badan Pembinaan Hukum Nasional (BPHN), setiap pelaksanaan upaya paksa selalu ada perenggutan HAM, meski hakikat penegakan hukum sesungguhnya adalah untuk melindungi HAM. Oleh karena itu, upaya paksa sepatutnya diupayakan agar tidak berlebihan dan dilakukan secara proporsional sesuai tujuan awal diadakannya upaya paksa. Sementara pemeriksaan praperadilan yang dimaksudkan sebagai kontrol atas upaya paksa, justru baru dilakukan setelah upaya paksa selesai dan sebelum dimulainya pemeriksaan mengenai pokok perkara. Sehingga, menurut BPHN, praperadilan merupakan pengawasan yang lebih bersifat "represif ", bukan preventif. ${ }^{16}$

Pemeriksaan praperadilan tidak memedulikan apakah penyidik atau jaksa yang menahan telah memenuhi seluruh persyaratan materil. Ada tidaknya bukti permulaan yang cukup, dalam praktiknya tidak pernah dipermasalahkan oleh hakim praperadilan, karena umumnya mereka menganggap hal itu bukan tugas dan wewenangnya, melainkah sudah memasuki materi pemeriksaan perkara yang menjadi wewenang hakim Pengadilan Negeri. ${ }^{17}$

Demikian pula dalam penahanan, hakim tidak melihat apakah tersangka atau terdakwa yang diduga keras melakukan tindak pidana berdasarkan bukti yang cukup, atau apakah memang ada alasan yang konkrit dan nyata, yang menimbulkan kekhawatiran bahwa yang bersangkutan akan melarikan diri, menghilangkan alat bukti atau mengulangi perbuatannya. Para hakim praperadilan umumnya menerima saja bahwa kekhawatiran merupakan urusan penilaian subjektif dari pihak penyidik atau penuntut. Dengan kata lain, hakim menyerahkannya kepada pihak penyidik dan penuntut umum. ${ }^{18}$

\section{Solusi Dari Hambatan Dalam Pelaksanaan Fungsi Dan Peran Praperadilan Dalam Penegakan Hukum Di Polda Jateng}

Penyidikan polisi merupakan proses untuk membuktikan bahwa seorang tersangka/terdakwa betul-betul melakukan tindak pidana, sehingga proses ini adalah rangkaian kegiatan mengumpulkan

\footnotetext{
${ }^{15}$ Amiruddin dan Zainal Asikin,2008. Pengantar Metode penelitian Hukum, Raja Grafindo Persada,Jakarta.hlm.85

${ }^{16}$ Maria Farida Indrati Soeprapto, 1998, IImu Perundang-undangan (Dasar-dasar dan Pembentukannya), Kanisius, Yogyakarta hlm.85

${ }^{17}$ Sudargo Gautama, 1973, Pengertian tentang Negara Hukum, Liberty, Yogyakarta, hlm. 113.

${ }^{18}$ E. Utrecht, 1959, Pengantar dalam Hukum Indonesia, Cetakan keenam, PT.Penerbit Balai Buku Ichtiar, Jakarta, hlm. 113.
} 
dan memperdalam alat bukti yang sah, sebagai alat untuk membuktikan di pengadilan. Seorang terdakwa harus betul-betul melakukan tindak pidana, dan karenanya pantas dijatuhi sanksi pidana. Pengadilan yang akan menguji apakah dakwaan penuntut umum beserta bukti-bukti yang diajukan dapat dijadikan sebagai alat bukti yang sah untuk mempidanakan seseorang. ${ }^{19}$

Diperlukan adanya upaya kontrol terhadap setiap aparat penegak hukum pada lembaganya masing-masing secara vertikal, meskipun pengawasan ini tidak cukup kuat karena sangat tergantung dari kesungguhan dan kemauan internal lembaga itu sendiri. Oleh karena itu diperlukan pengawasan horizontal, yang dilakukan secara sejajar atau pengawasan dalam tingkat yang sama.

KHN menyimpulkan bahwa KUHAP perlu direvisi khususnya mengenai mekanisme saling mengawasi antara penegak hukum dan lembaga dalam subsistem peradilan. Maksudnya antara penyidikan, penuntutan, pembelaan, pemeriksaan hakim dan tingkat upaya hukum. Selain itu, KHN menyimpulkan, ketentuan praperadilan dalam KUHAP hanya sebatas menguji (examinator judge) sah atau tidaknya penangkapan, penahanan, penghentian penyidikan atau penghentian penuntutan tetapi tidak meliputi menguji tindakan menyimpang dari penyidik jadi di harapkan dari posisi examinator judge harusnya menjadi investigating judge. Oleh karena itu, menurut KHN, lembaga praperadilan sebagai instrumen pengawasan perlu diperluas lingkup kewenangannya atas penyalahgunaan kewenangan oleh aparat penegak hukum, sehingga tidak merugikan hak pencari keadilan. ${ }^{20}$

Bukti permulaan yang cukup (probable cause) dan adanya alasan keperluan dan memenuhi syarat keperluan dan memenuhi syarat secara juridis (reasonablessnes) untuk menahan, tidak masuk dalam ruang lingkup yuridis praperadilan. Padahal secara konseptual praperadilan dimaksudkan untuk perlindungan kekuasaan penyidik. Ini karena pada dasarnya yurisidksi praperadilan itu hanya terbatas pada masalah pengujian keabsahan (pos factum) atas penangkapan dan penahanan secara keliru. ${ }^{21}$

Tidak terjaganya proses yang adil dalam tahap praajudikasi mengakibatkan tidak efektifnya tahap ajudikasi, karena perkara yang disidangkan tidak dipersiapkan pembuktiannya secara benar. Akibatnya, hakim bekerja keras di tengah ketidaktahuan tentang yang sebenarnya terjadi dalam tahapan praajudikasi. Tidak mengherankan jika banyak terjadi penolakan terhadap berita acara pemeriksaan oleh terdakwa atau saksi di tahapan ajudikasi (persidangan). ${ }^{22}$

Dalam tahap ajudikasi, hakim seharusnya berkonsentrasi penuh untuk menentukan hasil pembuktian di persidangan dan dalam tahap ini pula, hakim dapat menilai apa yang terjadi dalam tahap praajudikasi dan apa yang seharusnya dilaksanakan dalam tahap purna ajudikasi. Efektivitas tahap ajudikasi ini sangat dipengaruhi oleh apa yang terjadi dalam tahap praajudikasi. ${ }^{23}$

Karena tidak ada forum yang berwenang memeriksa dan mengevaluasi, sampai saat ini masih banyak penyalahgunaan kekuasaan dan kesewenang-wenangan dalam hal penangkapan dan penahanan terhadap seorang tersangka/terdakwa oleh pihak penyidik/penuntut umum. Padahal dalam sistem habeas corpus, hal ini justru menjadi tonggak ujian sah tidaknya penahanan terhadap

\footnotetext{
${ }^{19}$ Ibid, ICJR : h/m.87

${ }^{20}$ Menguak Misi KHN dan Kinerjanya, Kilas Balik 6 Tahun KHN RI (2006), hal. 37.

${ }^{21}$ KHN, Kajian terhadap Rancangan Undang-Undang Kitab Undang-Undang Hukum Acara Pidana (RKUHAP), 2009.

${ }^{22}$ Ibid. KHN. Kajian terhadap,.. hlm.89

${ }^{23}$ Ibid, ICJR : hIm.90
} 
seseorang ataupun boleh tidaknya seseorang ditahan. Oleh karena itu, tidak tepat jika hakim, melalui praperadilan, hanya memeriksa bukti formil dan mengenyampingkan fakta yang terjadi (materil). Peran hakim yang seperti demikian, menyimpangi tujuan proses peradilan pidana yang mencari kebenaran materil. Sangat sulit mengharapkan kebenaran materil jika dalam tahapan praajudikasi karena hakim hanya memeriksa bukti formil saja sebagaimana dipraktikan dalam praperadilan. ${ }^{24}$ Sehingga, diperlukan peran aktif hakim dalam menggunakan kewenangannya pada saat pemeriksaan pokok perkara untuk mempertimbangkan penyidikan atau penuntutan yang tidak sesuai dengan ketentuan hukum acara atau yang melawan hukum daripada hanya sekedar menunggu adanya permohonan dari para pemohon yang merasa haknya dilanggar atau dirugikan atas tindakan hukum yang dilakukan oleh penyidik atau penuntut umum dan permohonan ganti kerugian.

\section{PENUTUP}

\section{Kesimpulan}

1. Maksud dan tujuan utama yang hendak ditegakkan dan dilindungi, dalam proses praperadilan yaitu tegaknya hukum dan perlindungan hak asasi tersangka dalam tingkat pemeriksaan penyidikan dan penuntutan. Pasal 1 butir 10 KUHAP dipertegas dalam Pasal 77 KUHAP yang menyebutkan Pengadilan Negeri berwenang untuk memeriksa dan memutus, sesuai dengan ketentuan yang diatur dalam undang-undang. Wewenang pengadilan untuk mengadili dalam praperadilan dijelaskan dalam Pasal 95 KUHAP.

2. Hambatan dalam pelaksanaan fungsi dan peran praperadilan dalam penegakan hukum di Polda Jateng meliputi :

a. hakim lebih banyak memperhatikan perihal dipenuhi atau tidaknya syarat-syarat formil penangkapan dan penahanan, atau ada tidaknya perintah penahanan dan sama sekali tidak menguji dan menilai syarat materilnya.

b. setiap pelaksanaan upaya paksa selalu ada perenggutan HAM.

c. pemeriksaan untuk melakukan penahanan, masih ada penyalahgunaan dalam tahap penyidikan oleh Polisi dan penuntutan oleh jaksa.

d. selain luasnya kewenangan penyidikan dalam menentukan bukti permulaan yang cukup, pengawasan terhadap kewenangan tersebut juga lemah.

3. Solusi dari hambatan dalam pelaksanaan fungsi dan peran praperadilan dalam penegakan hukum di Polda Jateng meliputi :

a. Diperlukan upaya kontrol terhadap setiap aparat penegak hukum pada lembaganya masingmasing secara vertikal, meskipun pengawasan ini tidak cukup kuat karena sangat tergantung dari kesungguhan dan kemauan internal lembaga itu sendiri.

b. KUHAP perlu direvisi khususnya mengenai mekanisme saling mengawasi antara penegak hukum dan lembaga dalam subsistem peradilan.

\footnotetext{
${ }^{24}$ Ibid, ICJR : hlm.91
} 
c. diperlukan peran aktif hakim dalam menggunakan kewenangannya pada saat pemeriksaan pokok perkara untuk mempertimbangkan penyidikan atau penuntutan yang tidak sesuai dengan ketentuan hukum acara atau yang melawan hukum guna menghindari penyalahgunaan HAM.

d. dalam tahap ajudikasi, hakim seharusnya berkonsentrasi untuk menentukan hasil pembuktian di persidangan dan dalam tahap ini, hakim dapat menilai apa yang terjadi dalam tahap praajudikasi dan apa yang seharusnya dilaksanakan dalam tahap purna ajudikasi.

\section{DAFTAR PUSTAKA}

\section{A. Buku}

Amiruddin dan Zainal Asikin,2008. Pengantar Metode penelitian Hukum, Raja Grafindo Persada,Jakarta.

Darwan Prinst, 1993. Praperadilan Dan Perkembangannya Di Dalam Praktek . Citra Aditya Bakti, Bandung.

E. Utrecht, 1959, Pengantar dalam Hukum Indonesia, Cetakan keenam, PT.Penerbit Balai Buku Ichtiar, Jakarta.

Ediwarman, 2010. Monograf, Metodologi Penelitian Hukum, Medan: Program Pascasarjana Universitas Muhammadiyah Sumatera Utara, Medan.

Manullang, E.Fernando M., 2007, Menggapai Hukum Berkeadilan, Penerbit Kompas, Jakarta.

Maria Farida Indrati Soeprapto, 1998, Ilmu Perundang-undangan (Dasar-dasar dan Pembentukannya), Kanisius, Yogyakarta.

Moch. Faisal Salam,2001. Hukum Acara Pidana Dalam Teori dan Praktek, Mandar Maju. Bandung.

Ratna Nurul Alfiah,1986. Praperadilan dan Ruang Lingkupnya, Akademika Pressindo, Jakarta.

Sudargo Gautama, 1973, Pengertian tentang Negara Hukum, Liberty, Yogyakarta.

Sudargo Gautama, 1973, Pengertian tentang Negara Hukum, Liberty, Yogyakarta.

Wolfgang Friedmann, 1967, Legal Theory, Stevens \& Sons, London.

\section{B. Perundang-undangan}

Kitab Undang-Undang Hukum Acara Pidana.

Undang-Undang Nomor 8 Tahun 1981 tentang Kitab Undang-Undang Hukum Acara Pidana.

C. Internet

http://www.hukumonline.com

http://nasional.kompas.com/read/2017/09/30/08450451/kronologi-novanto-tersangka-hinggastatus-tersangkanya-dibatalkan. 